\title{
COLLABORATIVE POLICY-MAKING, LAW STUDENTS, AND ACCESS TO JUSTICE: THE REWARDS OF DESTABILIZING INSTITUTIONAL PATTERNS
}

\author{
Brea Lowenberger \\ Michaela Keet \\ Janelle Anderson*
}

Heightened concerns and dialogue about access to justice have infused the law school setting in Saskatchewan and, to varying degrees, across the country. If there ever were a time to approach social justice reform differently - to upset traditional parameters around decision making and step around older hierarchies for input and design - it would be now. This article describes the Dean's Forum on Dispute Resolution and Access to Justice (colloquially known as the Dean's Forum) as a platform for genuine student engagement in the development of public policy in this important area. We offer our combined reflections, gathered inside our "teaching team," about the unique pedagogical features of our experiment and its challenges. As we continue to grow with the project, we offer this Saskatchewan story as one example of institutional collaboration in a quickly evolving educational and social policy landscape.

L'accès à la justice est une préoccupation croissante et un thème de plus en plus récurrent dans les facultés de droit de la Saskatchewan et, à différents degrés, de l'ensemble du pays. Le temps est venu, semble-t-il, d'aborder la réforme de la justice sociale différemment, de bouleverser les paramètres traditionnels gravitant autour de la prise de décisions et de contourner les hiérarchies plus anciennes en ce qui concerne les données et les concepts. Cet article porte sur le forum du doyen concernant le règlement des conflits et l'accès à la justice (familièrement appelé le Dean's Forum (forum du doyen)) comme plateforme pour la participation des étudiants à l'élaboration des politiques publiques dans cet important domaine. Nous présentons l'ensemble des réflexions de notre équipe d'enseignants au sujet des éléments pédagogiques uniques de notre expérience et des difficultés connexes. Nous continuons à grandir avec notre projet, mais nous souhaitions décrire dès maintenant cette expérience vécue en Saskatchewan à titre d'exemple de collaboration institutionnelle dans un contexte dans lequel les politiques éducationnelles et sociales ne cessent d'évoluer.

Much of legal education simply accepts existing social, political, and economic arrangements as givens neither open to, nor worthy of, serious consideration and critique. In doing so, legal education communicates to students that, as lawyers, their role is not to seek substantive change to the existing order

\footnotetext{
Brea Lowenberger is the access to justice coordinator and director of CREATE Justice (the Centre for Research, Evaluation, and Action towards Equal Justice) in the College of Law at the University of Saskatchewan. In 2013-2014, she was a student on "the ground floor" of the project described in this article, as was Janelle Anderson. Janelle is now Crown Counsel with the Innovation Division at the Saskatchewan Ministry of Justice. In 2014-2015, Lowenberger and Anderson joined the Faculty of Law in adjunct positions and co-taught the second iteration of the course. Michaela Keet is on faculty at the College of Law and on the Steering Committee for CREATE Justice, taught the course at the outset, and has remained involved with the project. The authors would like to thank colleagues and professors Beth Bilson, QC, and Sarah Buhler for their feedback on earlier drafts of the article.
} 
but, rather, to get what they can for their clients within that order. ${ }^{1}$ In an increasing number of Canadian law schools, students are being encouraged to take up Janet Mosher's challenge, issued twenty years ago among a plethora of critiques about the messages embedded in legal education. Clinical models of teaching, in particular, invite students to consider the social location of clients and to explore models of legal advocacy that can be used to advance substantive change at individual cases or systemic levels. ${ }^{2}$ The philosophical and emotional tension felt by students in clinical placements has had a powerful impact on students' conceptions of professional and personal identities and on their relationship with legal institutions. ${ }^{3}$ These models have proven effective at surfacing systemic factors inherent to justice outcomes; they can and do lead students to adopt critical and sensitive models for lawyering. However, Mosher's critique and, by extension, its invitation to engage in critical and transformative analysis of legal and social institutions themselves has had less formal response from, or reflection in, the legal academy until recently.

Over the latter part of the past decade, heightened concerns about access to justice have begun to infuse the law school setting in Saskatchewan. The national dialogue in response to the "access-to-justice crisis" has focused critical attention on legal institutions and processes within the existing legal social order, calling for reform. Not surprisingly, law students have joined the force of critical thinkers anxious to be agents of social change. If there ever were a time to approach social justice reform differently - to upset traditional parameters around decision making and step around older hierarchies for input and design - it would be now. This article describes the Dean's Forum on Dispute Resolution and Access to Justice (colloquially known as the Dean's Forum) at the University of Saskatchewan College of Law as a platform for genuine student engagement in the development of public policy. The Dean's Forum is an initiative that began in 2013, co-chaired by the University of Saskatchewan's dean of the College of Law and Saskatchewan's deputy minister of justice, which brings together justice stakeholders to engage in dialogue about how to improve access to justice and dispute resolution in the province. An upper-year experiential course at the College of Law developed alongside the Dean's Forum, formally engaging students in consultation and research to support, facilitate, and participate in the dialogue at the Dean's Forum. The fifth Dean's Forum was held in March 2017. Stakeholders continue to see it as "their" forum to some extent, a middle ground where participants can continue to wrestle with goals and concerns and brainstorm possibilities for action. The enduring impact of the Dean's Forum on the design and delivery of justice services in Saskatchewan deserves exploration, but this article focuses instead on "forms of engagement" - the internal experience of the project and its impact on students, participants, and consultative structures.

Saskatchewan's experiment is innovative in that it made room for frank, collaborative dialogue in the exploration of a plan for access to justice at the institutional level and gave law students a central role in this process. In this article, we offer our combined reflections, gathered inside our teaching team, about the unique pedagogical features of our experiment and its challenges. As we continue to grow with the

Janet Mosher, "Legal Education: Nemesis or Ally of Social Movements" (1997) 35 Osgood Hall LJ 613 at 625.

Typically, experiential learning opportunities inside the law school focus on direct client experiences through clinics or externships, where it would be usual for the scope of the student's work to focus on advocacy and research for the client (the organization or the individual). Whether through student reflection or client service, most clinics encourage their students to look beyond individual client interests to collective experiences - collective disadvantage - inside the justice system. Role concepts such as the "legislative lawyer," "grassroots campaigns," and "community lawyering" help students consider how the law can be used to advance an agenda with social justice impact. See e.g. Hina Shah, "Notes from the Field: The Role of the Lawyer in Grassroots Policy Advocacy" (2015) 21:2 Clinical L Rev 393.

3 Sarah Buhler, "'I Am Not a Caped Crusader': Clinical Legal Education and Professional Identity Formation” (2016) 49 UBC L Rev 105. 
project, we offer this Saskatchewan story as one example of institutional collaboration in a quickly evolving educational and social policy landscape. The article is both descriptive, telling our story about this project, and reflective, drawing on a 360-degree internal perspective. As we have traveled through the heart of the project in the last four years, we have each taken on different roles and can now offer our views as teachers and students. Our reflections - on the Dean's Forum, on our action-oriented approach to its design, and on its characteristics as an educative environment for social change - are offered in the hope that they may continue to support the growth of meaningful experiential projects for law students and creative templates for the development of public policy. ${ }^{4}$

\section{A WINDOW OF OPPORTUNITY FOR LAW STUDENTS TO ENGAGE IN COLLABORATIVE POLICY-MAKING}

\section{A. The Educative Environment: A Time of Change}

The creation of the Dean's Forum occurred at a time of dilemma and opportunity, just prior to Canada's loudest call for action to improve access to justice across the country. This call to action was motivated by the release of two touchstone reports: the National Action Committee on Access to Justice in Civil and Family Matters' report entitled Access to Civil and Family Justice: A Roadmap for Change, chaired by the Honourable Thomas Cromwell, and, concurrently, the Canadian Bar Association's [CBA] report entitled Reaching Equal Justice: An Invitation to Envision and Act. ${ }^{5}$ These touchstone reports included a range of recommendations for accessible, equal justice and inspired creative solutions for a serious problem. The idea of the Dean's Forum preceded, but was given new energy by, the two reports.

The Dean's Forum also came along at a time of deeper reflection - and commitment to connecting reflection, theory, and practice - inside legal education, among demands that we "think critically and creatively about the role law schools can and should play in advancing social justice." ${ }^{6}$ Multiple forces

4 On 4 March 2016 the Canadian Bar Association's Legal Futures Initiative and the Canadian Bar Review hosted a symposium entitled Transforming Legal Education and Training in Canada: Learning across Life Stages. The symposium involved a day of brainstorming between legal educators, students, and practitioners on reforming legal education. The symposium was hosted through a design-thinking format, which is used as a strategy for innovation, putting the needs of the user - in this case, the law student - at the centre of the reform. In fact, there has been a rapid growth of ideas on system design as a creative template for the development of public policy, including thinking about how human-centred design can improve access to justice for the public and including students in that design-thinking process. Offered by the Winkler Institute for Dispute Resolution at Osgoode Hall Law School, the Justice Design Project (JDP) offers students the opportunity to work in interdisciplinary project teams to tackle a design challenge that addresses a real justice problem. See Winkler Institute for Dispute Resolution, "Justice Design Project," online: $<$ http://winklerinstitute.ca/justice-design-project/>. See also Stanford Law School's new course, introduction to legal design, a "9-week course for law students and other graduate students to reimagine how legal services are delivered, [and] learn how to use human-centered design methods to create breakthrough solutions to complex problems." Stanford Law School Course Catalogue, "Introduction to Legal Design," online: $<$ https://law.stanford.edu/courses/introduction-tolegal-design/>. For more information on the design process in the context of improving the justice system, see e.g. Open Law Lab, "Design Process," online: <http://www.openlawlab.com/approach-process/design-process/>.

5 Action Committee on Access to Justice in Civil and Family Matters, Access to Civil and Family Justice: A Roadmap for Change (Ottawa: Action Committee on Access to Justice in Civil and Family Matters, October 2013), online: $<$ http://www.cfcj-fcjc.org/sites/default/files/docs/2013/AC_Report_English_Final.pdf $>$ [Roadmap for Change]; Canadian Bar Association (CBA), Access to Justice Committee, Reaching Equal Justice: An Invitation to Envision and Act (Ottawa: CBA, November 2013), online: <http://www.cba.org/CBAMediaLibrary/cba_na/images/Equal\%20Justice\%20\%20Microsite/PDFs/EqualJusticeFinalReport-eng.pdf> [Reaching Equal Justice].

6 Adam Vasey, Social Justice Externship Report (Windsor: University of Windsor, November 2015) at 3, online: $<\mathrm{http}: / /$ www.uwindsor.ca/law/sites/uwindsor.ca.law/files/cljf-sj-externships_final_report.pdf $>$. Many earlier reports and articles track the way that "access to justice" has expanded from individualized strategies ("access to a lawyer") to more 
have inspired critical thinking around people's engagement with justice and the resulting shifts in the way law is being taught. ${ }^{7}$ For example, every law school across Canada has been called upon to rethink both how and what we teach in order to implement recommendations from the Truth and Reconciliation Commission of Canada's report. ${ }^{8}$ An increased commitment to clinical learning and community partnerships and outreach has taken root across Canada, including in Saskatchewan's law school and university.

With this increased commitment, and like some of its counterparts in other regions of the country, the College of Law at the University of Saskatchewan has embraced multiple ways for students to learn about and contribute to social, political, and legal change. ${ }^{10}$ In a two-year period, for example, three courses

integrated approaches and larger conceptions of social and economic justice. See e.g. Roderick A Macdonald, "Access to Justice and Law Reform no 2" (2001) 19 Windsor YB Access to Just 317; Patricia Hughes \& Mary Jane Mossman, "ReThinking Access to Criminal Justice in Canada: A Critical Review of Needs and Responses" (2002) 13 Windsor Rev Legal Soc Issues 1; Patricia Hughes, "Law Commissions and Access to Justice: What Justice Should We Be Talking About?" (2008) 46 Osgoode Hall LJ 773; Kent Roach \& Lorne Sossin, "Social and Public Policy: Access to Justice and Beyond" (2010) 60 UTLJ 373; Marc Galanter, "Access to Justice in a World of Expanding Social Capability" 37 Fordham Urb LJ 115.

7 See e.g. A Roadmap for Change, supra note 5 at 21-22; Reaching Equal Justice, supra note 5 at 120-123. See also Canadian Bar Association Futures Initiative, Transforming the Delivery of Legal Services in Canada (Ottawa: CBA, August 2014) at 57, online: <http://www.cba.org/CBA-Legal-Futures-Initiative/Reports/Futures-Transforming-theDelivery-of-Legal-Service $>$.

8 See call to action to law schools to improve intercultural competencies in curriculum at Recommendation 28 of the Truth and Reconciliation Commission of Canada, "Honouring the Truth, Reconciling for the Future: Summary of the Final Report of the Truth and Reconciliation Commission of Canada" (2015) at 323, online: <http://www.trc.ca/websites/trcinstitution/index.php? $p=890>$. A resulting online "community of practice" for teaching in this area was created by the University of Victoria, "Reconciliation Syllabus," online: <https://reconciliationsyllabus.wordpress.com $>$.

9 Clinical legal education has secured its spot in the Canadian law curriculum (see Sarah Buhler, "Introduction: The Association for Canadian Clinical Legal Education (ACCLE) Conference 2012" (2013) 37 Man LJ 357), and its potential to teach much more than "skills' is increasingly being acknowledged (see Lorne Sossin's influential paper, "Experience the Future of Legal Education" (2013) 47 Comparative Research in Law \& Political Economy, online: $<$ http://digitalcommons.osgoode.yorku.ca/clpe/289>). For a critical discussion of current challenges faced inside clinical legal education, see Gemma Smyth, "Clinical and Experiential Learning in Canadian Law Schools: Current Perspectives" [forthcoming; cited with permission]. The Association for Canadian Clinical Legal Education was created in 2010 to provide a forum for legal educators and clinics across Canada. Association for Canadian Clinical Legal Education, online: $<$ http://accle.ca/>. More recently, the theme for Congress 2016, held in Calgary, was "Energizing Communities," and the 2016 Canadian Association of Law Teachers' Conference, "Energizing Communities through Legal Education" focused solely on the recommendations around Reconciliation and improving access to justice. Canadian Association of Law Teachers' Conference, online: <http://www.acpd-calt.org/conference>. For example, some access-to-justice course innovations across Canada include the development of three new justice innovation and accessto-justice courses at Osgoode Hall Law School. See Nicole Aylwin, "Justice Innovation and Access to Justice Program Report" (Toronto: 2016), Winkler Institute for Dispute Resolution, online: $<$ http://winklerinstitute.ca/wpcontent/uploads/2016/07/July-21-Online-PDF.pdf $>$ ) and an access-to-justice course taught by Federation of Law Societies President Jeff Hirsch at the University of Manitoba (see the course description, online: $<$ http://law.robsonhall.com/current-students1/course-descriptions/access-to-justice/>). Locally, the University of Saskatchewan's third Integrated Plan focuses on the areas of culture and community along with innovation in academic programs and services, Aboriginal engagement, and knowledge creation. See University of Saskatchewan, "Planning Progress," online: <http://www.usask.ca/plan/index.php>).

That is not to say that there is unanimity on the question of should - and can - law schools meaningfully participate in a mission for social change. While Gemma Smyth notes widespread support for clinical legal education in Canada, she also notes the mix of motives or perceptions about what can be accomplished: "Deans were aware that their clinics provided some measure of support to community members, but they were also circumspect about law schools' ability to solve, or even make significant inroads, into access to justice-related problems.," concluding that, "(t)his question - are 
were created with related goals: the access to justice seminar (2013) to develop students' understanding of the social reality of law; a course on systemic justice (2015) to examine root causes of injustice by placing students in experiential learning projects that address systemic barriers facing marginalized people; and a revived law reform course (2013), which places students in groups to undertake research and write reports exploring legislative changes related to a specific law reform initiative. ${ }^{11}$ Other courses envision transformation in the way knowledge - and, ultimately, justice relationships - are developed. For example, a collaborative course called "Wahkohtowin" ("kinship" in Cree), involves pairing lawyers, youth, and students as co-learners and co-creators of knowledge with members of a community organization for former gang members, who have lived experience with the impacts of law and the justice system, creating space to imagine justice together. ${ }^{12}$

These recent innovations are preceded by a rich history of access-to-justice and dispute resolutionrelated course development at the College of Law at the University of Saskatchewan. Since the establishment of CLASSIC, a legal clinic located in Saskatoon's core neighbourhood staffed mostly by law students, short- and longer-term clinical placements have been available in the curriculum. In 2005, an innovative inter-professional law and psychiatry course was created (having first been introduced in 1976), ${ }^{13}$ and, in 2010, an intensive dispute resolution program for first-year students was established ${ }^{14}$ (having been integrated into the first-year curriculum in the late 1990s). Faculty and student interest in the topic of access to justice, which is motivated by the desire to "do law differently," is keen. ${ }^{15}$

\section{B. The Public Policy Environment: Desire for Action on Access to Justice}

At the same time, interest was gathering among justice stakeholders for a different kind of dialogue and a made-in-Saskatchewan approach. The Dean's Forum initiative was initiated and chaired jointly by the deputy minister of justice for Saskatchewan and the dean of the College of Law. It was imagined as a consultative and direction-setting process for justice policy in this province on "access to justice and dispute resolution," one that would focus quickly on action in three ways: it needed to be responsive to the problem of access to justice; it needed to be a collaborative and candid conversation; and it needed to be forward-looking, focused more on brainstorming ideas for creative change than on information gathering and study. The project was meant to invoke an expansive, inclusive approach to what access to justice might mean - right here, right now. ${ }^{16}$

law schools responsible for access to justice, and, if so, what methods are possible and appropriate - is an interesting and persistent one that will undoubtedly play out over the next several years." Smyth, supra note 9 at 25, 26.

11 For more information, see curriculum information at University of Saskatchewan College of Law Upper Year Balloting, "2016-2017 Long Course Descriptions," online: < http://law.usask.ca/students/current-students/upper-year-

balloting.php>.

12 Sarah Buhler, "Reading Law and Imagining Justice in the Wahkohtowin Classroom" at 1 [forthcoming; cited with permission]. For more, see Sarah Buhler, Priscilla Settee \& Nancy Van Styvendale, "We Went in as Strangers, and Left as Friends: Building Community in the Wahkohtowin Classroom" (2016) 1 Engaged Scholar Journal: CommunityEngaged Research, Teaching, and Learning 96, online: <http://esj.usask.ca/index.php/esj/article/view/114>.

13 M. Mela \& G. Luther, "Law and Psychiatry Seminar: An Interprofessional Model for Forensic Psychiatric Training" (2013) 37 Acad Psychiatry 421 at 422.

14 University of Saskatchewan College of Law Dispute Resolution, "First Year Dispute Resolution: Client-Centred Advocacy," online: <http://law.usask.ca/experiential-learning/dispute-resolution.php>.

15 CBA Legal Futures Initiative, Do Law Differently: Futures for Young Lawyers (Ottawa: CBA, February 2016), online: $<$ http://www.cba.org/CBA-Legal-Futures-Initiative/Reports/Do-Law-Differently-Futures-For-Young-Lawyers>.

16 The first invitation to the Dean's Forum included readings suggesting "controversial approaches," framed this way in the letter of introduction: "The Dean's Forum gathering will encourage open, experience-based reflections on 'access issues' and dispute resolution processes (including litigation and court-based processes generally). Although the conversation will begin with 'the view from inside the justice system', we expect it will be informed by critical views ... All of these 
The conception of the Dean's Forum and its structure was experimental, going beyond more commonly employed ideas of external consensus building around governmental or organizational policy. ${ }^{17}$ It was envisioned as a process that would break away from institutional patterns for dialogue and decision making, which would be hosted at the college with other justice leaders attending on a level playing field. ${ }^{18}$ The first forum meeting included twenty-eight people who were thought of as potential internal decision makers inside the legal professional constituencies: the Chief Justice and justices of the Superior Courts, the chief judge of the Provincial Court, executive members from the Ministry of Justice, the Law Society of Saskatchewan, the Saskatchewan Branch of the CBA, and Legal Aid, among other justice and dispute resolution-related organizations. The Dean's Forum was given a significant boost by the strengths of the existing relationships among the stakeholder groups, including the College of Law. The process was designed to follow a problem-solving model, avoiding the more familiar conference or meeting formats typical inside academic or government settings (and this question of design is later relevant to our analysis of the opportunities it presented). Although the day began with a few presentations on "innovations" within the Saskatchewan courts, the provincial Ministry of Justice, and the profession, participants were quickly invited to participate in honest dialogue about what has worked and what has not. The questions posed were simple: what is the potential; what are the possibilities; and how do we move forward?

The day was facilitated in a way that was consistent with mediation, and participants were encouraged to trust the dialogue ('like any problem-solving process, we may not know right now where it will lead') and to apply brainstorming principles, separating the generation and evaluation of ideas. ${ }^{19}$ To set the stage and avoid the conservative overtones of an "on-the-record" debate, ground rules were set. Every participant was asked to join in his or her personal capacity as a professional with long-standing experience in the justice system but not as a representative of any organization. All dialogue in this meeting was to be treated as confidential so that no participant held back for fear of attribution. While some people presented in the morning, any questions and conversation that followed were to be informal, egalitarian, and balanced - and the distribution of seats around the boardroom table captured this message.

By the end of the first forum gathering, the group had identified three areas to focus reform efforts: (1) early integrated "triage" service centres; (2) public information at critical gaps; and (3) engaging practising

materials are meant to encourage, but not limit, a creative-thinking process - to support a productive conversation about how to move forward." Michaela Keet \& Brent Cotter, "Some Readings on Access to Justice and Dispute Resolution" (September 2013) [unpublished]. Materials included Brent Cotter, "Thoughts on a Coordinated and Comprehensive Approach to Access to Justice" (2012) 63 UNBLJ 53; a written submission by M. Jerry McHale, Lam Chair in Law and Public Policy, University of Victoria [unpublished], and since the forum was held before the release of the final Cromwell report, excerpts from the four Working Group reports of the Action Committee on Access to Civil and Family Justice.

17 E.g., see Gerald Cormick et al, Building Consensus for a Sustainable Future: Putting Principles into Practice (Ottawa: National Round Table on the Environment and the Economy, 1996), online: $<$ http://publications.gc.ca/collections/collection_2016/trnee-nrtee/En133-10-1-1996-eng.pdf>.

18 The call to 'break patterns' dates back at least to Rod MacDonald's work in 1990, with a plethora of related literature composed by him since that time. In a recent piece, MacDonald states: "Today, some of Canada's most pressing social and economic problems do not lend themselves to legal resolution through orthodox research leading to legislative action. Appropriate policy responses require research into social, economic, and cultural contexts as well as into the full panoply of instruments available to facilitate cooperative action among governments and citizens." Roderick A MacDonald, "Law Reform for Dummies (3rd Edition)" (2014) 51 Osgoode Hall L J 859 at 886-887, 865 [MacDonald, "Law Reform for Dummies"].

19 Facilitative leadership styles, clear ground rules, and process transparency are all noted in the literature as accompaniments to a collaborative policy-making approach. See Chris Ansell \& Alison Gash, "Collaborative Governance in Theory and Practice" (2011) 18 Journal of Public Administration Research \& Theory 545 at $554,556$. 
lawyers in a legal culture shift. Participants decided that the Dean's Forum should continue as an actionoriented process and that interim project work would have to be done before a second meeting in order to take ideas and priorities to a concrete stage.$^{20}$ Here, the College of Law's role was serendipitous: students (as leaders of the future) should participate. This launched the creation of the Dean's Forum course, offering upper-year law students at the University of Saskatchewan College of Law a unique experiential learning opportunity to contribute to the design of justice policy.

\section{CREATING A PEDAGOGICAL STARTING POINT FOR AN EXPERIMENT IN COLLABORATIVE POLICY-MAKING}

As is often the case with experiential learning for law students, the opportunity came along before the pedagogical structure had been built. This has been noted as a common underlying dilemma with externships, in particular, ${ }^{21}$ but the development of pedagogical vision has been noted as a challenge across clinical and experiential programming more generally in the law school setting. ${ }^{22}$ In the case of externships, the separation between the supervision of work and the law school, where instruction normally occurs, has slowed the development of pedagogy: "Though much has been written on the value and process of reflection in the externship context, there has been little development of a learning structure to connect that reflection to the advancement of student skills and knowledge." ${ }^{23}$ The externship example is a useful lead-in to our discussion about course structure, in that externships may borrow from the more well-established clinical methodologies but ultimately need their own (perhaps custom-made) academic support system to be built around them. We faced the same challenge - and opportunity - in the inception of the Dean's Forum.

Although Saskatchewan law students have a strong pro bono ethic ${ }^{24}$ and volunteer student researchers could have been easily found, we viewed the opportunity as deserving more institutional backing. Elevated to the status of a course, a group of students could learn more, and contribute more, on a project that was far more than academic. Using the college's structure for special projects courses (allowing for short-term implementation), we advertised a course called "Innovation in Justice: Dispute Resolution and Access to Justice" in December 2013. Seven students applied, were accepted, and began work at the beginning of the next term, following the priorities identified by the first forum. Since then, four forum gatherings have been held. To meet the forum's goals, topics have had to be relevant, students' work focused and resourceful, institutional support available, and outcomes "high on the radar." All of these priorities were contemplated in the project's pedagogical design and sometimes reconceptualized as it evolved. Our strategies on these points are explained in the following sections.

20 Refer to College of Law, University of Saskatchewan, “Dean's Forum on Dispute Resolution and Access to Justice: Summary Notes from September 20, 2013" (2013) at 3, online: <http://law.usask.ca/documents/deansforum/01_FirstMeeting_2013SummaryNotes.pdf> [unpublished] for a summary of next steps from the initial gathering of the Dean's Forum.

21 Elizabeth G Ford, “Toward a Clinical Pedagogy of Externship” (2015) 22:1 Clinical L Rev 113.

22 Smyth, supra note 9 at 15.

23 Ford, supra note 21 at 115-116. That is not always true, and Adam Vasey's, supra note 6, externship report is a good example of pedagogy preceding the project.

24 According to the Pro Bono Students Canada (PBSC) University of Saskatchewan Chapter 2016/17 Project List, there are approximately 100 PBSC placements available, which amounts to approximately one-third of the student population engaged in a PBSC placement each year. Pro Bono Students Canada University of Saskatchewan Chapter, "Projects: 2016/17 Project List," online: <http://law.usask.ca/probono/Projects.php>. 


\section{A. Selecting Forum Topics}

Students have been divided into two groups each year to collaboratively research and develop actiondriven group policy discussion papers on one of two topics. Topics change for each Dean's Forum gathering and have been identified over the project's evolution in different ways. ${ }^{25}$ Each time, a number of factors are considered: which topics are ripe for a meaningful contribution, in Saskatchewan, right now; what project areas could benefit from the time and resources of student research groups and the neutral meeting ground of the College of Law; and what project areas are suitable for the creative, unencumbered, and practical skills and perspectives of law students?

The Dean's Forum reconvened in March 2014, this time with the first group of Dean's Forum course students and the Hon. Justice Thomas Cromwell and Jeff Hirsch, special guests from the Steering Committee of the National Action Committee on Access to Justice in Civil and Family Matters. The topics selected in 2014 addressed the themes identified during the initial meeting of the forum. The students explored: (1) integrated service centres (including public information at critical gaps) and (2) the culture of the legal profession. ${ }^{26}$ The Dean's Forum Steering Committee identified two themes for further exploration at the 2015 meeting of the forum participants, both of which built upon ideas raised in discussion among stakeholders in the first two meetings and expanded the Dean Forum's view to the academy and the profession. The first theme would look inward at the College of Law, seeking to understand the role that legal education plays in access to justice: through admissions; curriculum and degree requirements; experiential learning and clinical course offerings; research; and interdisciplinary connections. The second theme would look outward to explore the evolution of legal service delivery, seeking to explore whether the introduction of licensed non-lawyers or legal technicians could improve the delivery of legal services to Saskatchewan residents, considering the issues of education, regulation, scope of practice, and the challenges and successes experienced by other jurisdictions. ${ }^{27}$

The Dean's Forum course was offered in its third iteration during winter of 2016. There were, again, two themes chosen for exploration by the students and forum participants, this time identified through consultations completed by the access to justice coordinator and the support of the Saskatchewan Access to Justice Working Group (Working Group). The first theme involved critically engaging with the topic of "putting the public first" - that is, identifying who "the public' is and how different "publics" can

25 Dean's Forum topics have been identified previously by the Dean's Forum Steering Committee in 2014 and 2015 and, starting in 2016, in consultation with the Saskatchewan Access to Justice Working Group. The Dean's Forum Steering Committee was comprised of the Dean's Forum co-chairs, the dean of the College of Law at the University of Saskatchewan, and the deputy minister of justice and deputy attorney general for Saskatchewan, in addition to the Dean's Forum instructors. For more information on the Saskatchewan Access to Justice Working Group, see University of Saskatchewan College of Law, "Saskatchewan Access to Justice Working Group," online: College of Law $<$ http://law.usask.ca/find-people/saskatchewan-access-to-justice-working-group/index.php>.

26 To learn more about the substantive outcomes of the students' work, access copies of the student reports from the 2014 course offering at the University of Saskatchewan College of Law, "Justice Innovation and the Culture of Legal Practice" (13 March 2014), online: <http://law.usask.ca/documents/deansforum/01_FirstMeeting_2013SummaryNotes.pdf> [unpublished]; University of Saskatchewan College of Law, "Bridging the Gap: The Prospect of Integrated Service Centre" (13 March 2014), online: <http://law.usask.ca/documents/deansforum/03_TheProspectofIntegratedServiceCenters2014DeansForum.pdf> [unpublished].

27 To access copies of the student reports from the 2015 course offering, see the University of Saskatchewan College of Law, "Access to Justice: A Legal Education Initiative" (12 March 2015), online: <http://law.usask.ca/documents/ deansforum/09_LegalEducation_PolicyDiscussionPaper_2015DeansForum.pdf $>$ [unpublished]; University of Saskatchewan College of Law, "A Discussion Paper on Introducing Paralegals into the Saskatchewan Legal Market" (12 March 2015), online: <http://law.usask.ca/documents/deansforum/10_Non-LawyerLegalServices PolicyDiscussion_2015DeansForum.pdf $>$ [unpublished]. 
contribute meaningfully to more accessible justice. The second theme explored how the Court of Queen's Bench for Saskatchewan and its procedures could be more accessible to more people and more cases through, for example, early and active judicial case management and dispute resolution and further engaging lawyers in the new simplified and summary procedure rules of court. ${ }^{28}$ This theme was proposed by the court - a sign of the credibility of the Dean's Forum with the stakeholders.

During the winter of 2017, the Dean's Forum course was offered for a fourth time. The two themes were chosen again through consultations completed by the access to justice coordinator and with support from the Working Group. The first theme considered the distinction between legal information and legal advice in relation to access to justice, including an examination of a variety of contexts in which this distinction arises (for example, with librarians, courthouse staff, legal coaches, in licensing non-lawyer professionals, and so on). The second theme focused on expanding engagement, to identify how interdisciplinary partnerships between justice and health systems might improve access to justice for Saskatchewan residents. ${ }^{29}$ The identifying and selection of forum topics has caught on with stakeholders during the four iterations of the initiative. In addition to regular consultations that occur between the access to justice coordinator and stakeholders, members from justice organizations now contact the access to justice coordinator on an ongoing basis with ideas for potential forum topics. A 'Research Project Bank' has been created by the access to justice coordinator to capture the research ideas and continue to support the selection of forum topics.

\section{B. Preparing Students for a Lead Role in Policy Dialogue}

The course has been designed to introduce students to various roles during the four phases of the project, which are all essential to action-oriented policy development. ${ }^{30}$

\section{Foundational Research and Project Planning}

In what we have described as the "exploratory phase," students develop practical and academic points of reference for their topic, considering how to anchor their work in newly released policy documents, academic literature, and current developments in service and programs. As it has evolved, each student

28 To access copies of the student reports from the 2016 course offering, see University of Saskatchewan College of Law, "Putting the Public First" (29 February 2016), online: <http://law.usask.ca/documents/deansforum/12_PuttingthePublicFirst_PolicyDiscussionPaper_2016DeansForum.pdf $>$ [unpublished]; University of Saskatchewan College of Law, “'Action' to Justice: Addressing Access to Justice in the Saskatchewan Court of Queen's Bench" (29 February 2016), online: $<$ http://law.usask.ca/documents/deansforum/13_SuperiorCourtandCourtProcesses_PolicyDiscusion-

Paper_2016DeansForum.pdf $>$ [unpublished].

29 Copies of the student reports from the 2017 course offering will be made available. See the University of Saskatchewan College of Law Reports: Dean's Forum Library, online: <http://law.usask.ca/research/deans-forum/library.php>.

30 See e.g. Lawrence Susskind \& Jeffrey Cruikshank, "What Is Consensus?" in Lawrence Susskind et al, eds, The Consensus Building Handbook: A Comprehensive Guide to Reaching Agreement (Thousand Oaks, CA: SAGE Publications, 1999) 287. We were also guided by the process principles articulated by David Straus, "Managing Meetings to Build Consensus" in Susskind et al, ibid, the practical design principles in Cormick et al, supra note 17. A deeper theoretical examination of models of government and community planning and engagement are beyond the scope of this article but ought not to be overlooked. Early descriptions of contrasting models influential in the United States range from Saul Alinsky's conception of community advocacy (often seen as a "confrontation' model), captured in his book. Saul Alinsky, Rules for Radicals: A Pragmatic Primer for Realistic Radicals (New York: Random House, 1971) to collaborative models such as the "asset-based" approach to development captured by John P Kretzmann and John L Knight, Building Communities from the Inside Out: A Path toward Finding and Mobilizing a Community's Assets (Evanston, IL: Centre for Urban Affairs and Policy Research, Northwestern University, 1993). See also Ansell \& Gash, supra note 19, which examines the literature and the extent to which it addresses differences among adversarial, collaborative, and managerial governance models. 
working group now collaborates to develop a two-part action plan in the first week or two of the course. In Part "A," students complete a short summary of how the two reports, Access to Civil and Family Justice: A Roadmap for Change $e^{31}$ and Reaching Equal Justice: An Invitation to Envision and Act ${ }^{32}$ addressed the project topic; a list and description of related programs, innovations, and policies tried in Saskatchewan and elsewhere; and a short literature review with five to seven leading journal articles related to the project topic. This provides students with a current operational framework, which is meant to support creative thinking about the project topic without letting the students get bogged down. In Part "B" of the action plan, students synthesize this foundational research to plan and prepare an outline for the project. Students include a brief paragraph defining the specific problem; a list of the interest groups and the anticipated needs of the groups; a list of sub-themes and sub-tasks to complete for the project; a consultation plan to assess the Saskatchewan context, including a list of interviewees and interview questions; a discussion of potential pathways for implementation, including what steps would need to be taken and by whom; and initial thoughts on how to measure the success of the project.

After the first round of the Dean's Forum, materials were collected to assist students through the initial stages of the collaborative, co-creative experience. ${ }^{33}$ In 2016, the Strengths-Finder Assessment was introduced at the onset of the course as a way to tap into student strengths and encourage self and collective reflection among the students throughout the project. ${ }^{34}$ Guided by their Strengths-Finder results, students explored ways to structure their work to make the most of individual strengths and group orientations.

\section{Consultations, Discussion Paper, and Communications Strategy}

With a research framework and action plan behind them, students conduct consultation interviews with key stakeholders, exploring Saskatchewan experiences and priorities, illuminating what might not be captured in the empirical or academic literature. Consultations evolve each year, based on the project topic areas. By brainstorming together during the previous project-planning phase, students identify voices that should be part of an intensive consultation phase. Again, their orientation to this is "on the ground," not soliciting official positions of stakeholder groups but, rather, digging into personal views and observations from key informants about current strengths and gaps in the system. Students then consider how to present information and design a process with focused discussion and outcomes.

31 Roadmap for Change, supra note 5.

32 Reaching Equal Justice, supra note 5.

33 The new handouts that were created in 2016 to accompany those that were created in 2015 include "Creating Your Action Research Plan" and "Completing Your Follow-Up Reporting." As stated, these handouts, the syllabus, and other course materials are available upon request (please contact the Access to Justice Coordinator, online:

$<$ http://law.usask.ca/research/deans-forum/connect.php>).

34 The Strengths-Finder Assessment is available to students at the University of Saskatchewan through the Student Employment and Career Centre at a minimal cost. Strengths-Finder Assessment, online: $<$ https://students.usask.ca/jobs/careers.php>. The Student Employment and Career Centre reports that "[t]he Strengths-Finder is a 177-item assessment based on positive psychology that supports individuals in identifying their most natural ways of thinking, feeling and behaving (i.e., their raw talents)" and that it "helps students identify their raw talents and develop them into strengths." See Megan Marcoux, "Building Capacity for Effective Group Work" (15 August 2016), online: Educatus the Official Blog of the Gwenna Moss Centre for Teaching Effectiveness <http://words.usask.ca/gmcte/author/guest/> [unpublished]. Marcoux states that Strengths-Finder as a tool "give[s] groups of students the opportunity to enhance their self-awareness and deepen their competency development in the classroom," with one such competency focused on and developed through the tool, "the ability to work more effectively in teams, which is not only included in the learning outcomes associated with the Learning Goals of the University of Saskatchewan Learning Charter but also in the Career Readiness Competencies outlined by the National Association of Colleges and Employers (NACE)." 
Each group prepares a policy paper summarizing its research and identifying key ideas, themes, and points for further discussion - thinking about how to capture big ideas and trigger creative thought among the Dean's Forum participants. Students are pressed to develop a communication strategy to fit the project. They wrestle with how to convert large blocks of information into consumable reports; how to engage decision makers without overwhelming them with information. The reports they produce are practical and accessible: summarizing research and development without getting bogged down, capturing bigger dilemmas and ideas, and - in plain language - setting out a framework of possibilities for moving forward. They employ a style of writing that differs greatly from traditional academic writing. Draft policy discussion papers may be circulated among all interviewees for input and feedback and to further build the collaborative goals of the project.

\section{Planning to Engage Forum Participants}

Student groups also work together to design the Dean's Forum - to create invitation lists and develop an agenda and format that remains consistent with the success, and unique structure, of those preceding it. The structure of the agenda for the third Dean's Forum course offering in 2015 mirrored past iterations, but invitees were expanded to include additional members from community organizations and law school faculty, who were identified as having an interest in the topics, including the role that either licensing paralegals or legal education can play in improving access to justice. A greater number of members from the Law Society of Saskatchewan, for example, were invited to participate in relation to the paralegal topic. Again in 2016, the structure of the agenda was the same as in previous years, but the group of stakeholders who were invited to participate shifted in accordance with its new themes. For example, given that the Court of Queen's Bench procedures were addressed during the 2016 meeting, additional representatives from the court were invited. In 2017, the invitation list was expanded so that a number of health professionals could participate in the discussion about the delivery of justice and health services. The structure of the 2017 agenda also shifted to address one theme during the morning session and the other theme during the afternoon session. The aim of the new format was to involve a greater number, and a more inclusive group, of attendees by inviting different participants for either session.

Students also consider how to engage participants as they design their presentations. Students present their policy discussion papers using creative presentation techniques to engage participants at a level that "felt like it mattered." For example, one of the student groups during the 2014 Dean's Forum wove the profiles of two users of the system into their presentation in order to illustrate how integrated service centres could benefit different "publics" attempting to access the justice system. Other groups have used participatory ice-breaking exercises to illustrate conceptual shifts and dynamic, creative presentation styles. ${ }^{35}$ Following their presentations each year, the students have organized breakout groups with discussion guidelines to occur and then helped facilitate and record those conversations. Larger group discussions have typically occurred thereafter, and tangible next steps have been identified, including recommendations in some cases. Students act as scribes throughout the day, paying close attention to, and recording, key ideas, interests, concerns, and goals that arise during the forum discussion.

35 E.g., a group of students in 2017 used the fast-paced, multi-presenter format, PechaKucha, to keep the audience engaged and focused on the report's key themes. 


\section{Follow-up Reporting and Reflection}

Following the conclusion of each Dean's Forum, students summarize their meeting notes and contribute to a follow-up package sent to participants in order to clarify the next steps. ${ }^{36}$ Beginning in 2015, the instructor has engaged the students in a formal reflective writing exercise designed to facilitate individual reflection on their learning throughout the term. ${ }^{37}$ The students are posed with a range of questions focused on cognitive, affective, and process learning from which they can choose depending on what most resonated with their experience. From the instructors' perspective, the reflective exercise has been critical to the students' learning and growth from the experience, given the challenges and growth that may accompany both experiential learning and group work. ${ }^{38}$ With the introduction of the StrengthsFinder Assessment at the onset of the 2016 course offering, the reflective writing exercise also invited students in 2016 to meaningfully incorporate reference to their Strengths-Finder Assessment results in at least one of their responses. The instructor's observation and the students' anecdotal feedback has been that both the Strengths-Finder Assessment and the reflective writing exercise benefited the students' overall experience in the course. We were asking the students to take on high-level research and communication work in a small group setting, among students who did not know one another and had a very short window of time in which to figure out their plan, execute their research, and draft a sort of report that none of them had any experience with. The strengths-finder exercise enabled students to open up about their own strengths and tendencies and laid the groundwork to facilitate effective collaboration. The final reflective exercise has provided the students with an opportunity for meaningful and critical selfreflection at the conclusion of an intensive experience.

36 To access the follow-up package that was sent to participants at the 13 March 2014 meeting of the Dean's Forum, see "Appendix E: Summary of the Second Meeting of the Dean's Forum" in University of Saskatchewan, College of Law, "The Dean's Forum on Dispute Resolution and Access to Justice: The Saskatchewan Experience" (2014) at 64-65, online: <http://law.usask.ca/documents/deansforum/04_TheSecondMeeting_2014SummaryNotes.pdf $>$ [unpublished] [2014 Summary Notes]. As stated in the 2014 Summary Notes, the Ministry of Justice provided funding for two summer positions for University of Saskatchewan law students to "facilitate the ongoing work the Forum" on the topics of "early and integrated service delivery," "legal culture," and "future access to Justice initiatives" (at 64-65). For a record of the students' summer work, refer to the University of Saskatchewan, College of Law, "The Dean's Forum on Dispute Resolution and Access to Justice: Progress Report" (March 2015), online: <http://law.usask.ca/documents/deansforum/05_ProgressReportI_2014-2015.pdf> [unpublished] [Progress Report]. The Progress Report includes appendices of the three reports that were completed as a result of the students' summer work: (1) "Emerging Themes in Early and Integrated Service Delivery" (Appendix A at 6); (2) "Improving upon Early and Integrated Service Delivery" (Appendix $\mathrm{B}$ at 39); and (3) "Changes in the Culture of the Legal Profession" (Appendix C at 50). For a summary of the notes and next steps from the 2015 meeting of the Dean's Forum, refer to "Appendix A: Summary Notes of the Third Meeting of the Dean's Forum (March 12, 2015)" in University of Saskatchewan, College of Law, "The Dean's Forum on Dispute Resolution and Access to Justice: Progress Report II" (February 2016) at 10-22, online:

$<$ http://law.usask.ca/documents/deansforum/11_TheThirdMeeting_2015SummaryNotes_ProgressReportII_20152016.pdf $>$ [Progress Report II] [unpublished]. For a summary of the notes and next steps from the 2016 meeting of the Dean's Forum, refer to the University of Saskatchewan, College of Law, "Dean's Forum on Dispute Resolution and Access to Justice: Summary Notes from February 29, 2016" (2016), online: $<$ http://law.usask.ca/documents/deansforum/14_FourthMeeting_2016SummaryNotes.pdf> [unpublished] [Progress Report III].

37 A copy of the reflective writing exercise can be made available upon request (please contact the Access to Justice Coordinator with your interest, online: $<$ http://law.usask.ca/research/deans-forum/connect.php >).

38 See e.g. Michele Leering, "Conceptualizing Reflective Practice for Legal Professionals" (2014) 23 J L \& Social Policy 83, online: <http://digitalcommons.osgoode.yorku.ca/jlsp/vol23/iss1/5> at 100 [Leering, "Conceptualizing Reflective Practice"]. 


\section{B. Institutional Resources and Structure behind the Initiative}

Even beyond conceptual questions about how to structure this educational project for students, the College of Law had to consider resources it would need to be sustainable. Continuing the project's independent framework was seen as critical, creating an environment that facilitated engagement, collaboration, and co-creativity among students, instructors, and stakeholders on a level playing field. With the original two faculty members moving into 2015 with full course loads, the Dean's Forum Steering Committee encountered a challenge in how to deliver and facilitate the course a second time. We reached 'back into the project' to find the momentum and guidance for moving it forward, inviting two student graduates who had participated in the previous offering of the Dean's Forum course to return to the college to co-instruct its next offering. The promotion of recent graduates to positions of formal leadership challenged power structures inherent in the educative environment, especially those derived from students' learned experience in other law school courses. The challenge this presented is analyzed further in the third part of this article.

Building on the course's first round of success - and hoping to add breadth to the opportunities it presented to students - we decided to expand the second course offering from seven to ten students. "Structure" was also added to guide the students and equip them with tools to navigate the expectations associated with the projects. Additions included a detailed syllabus that divided the course and classroom sessions into set phases for the project and a weekly reading list that provided additional academic and theoretical support on the processes used in collaborative policy-making. ${ }^{39}$ Added structure, however, summoned the typical trappings of a formalized didactic lecture style, and adaptations had to be made to maintain the co-creative environment necessary for the project's success. Students were assigned leadership roles to plan classroom sessions, circulate agenda items, and serve as chairpersons to lead discussions. This small adjustment signalled the transfer of power from instructor to student and reinforced group ownership over the project.

There were a number of recommendations implemented following the 2015 offering of the course, which enabled the project to gain even more momentum. ${ }^{40}$ In recognition that the project required institutional resources, an access to justice coordinator position was created. ${ }^{41}$ The coordinator was tasked with supporting the implementation of recommendations from previous meetings of the Dean's Forum; co-creating the Working Group; and teaching the Dean's Forum course and transitioning the Working Group and the Dean's Forum to new topic areas aimed at improving access to justice. The access to justice coordinator concurrently liaised and formed partnerships with justice stakeholders, students, and the community at large to implement recommendations and related initiatives to the Dean's Forum that promote justice reform and access to justice. ${ }^{42} \mathrm{With}$ this project gaining momentum and generating energy

39 Handouts such as "Planning Your Policy Discussion Paper," "Designing the Dean's Forum," and "Designing Your Presentation" were developed to help navigate the students through the process. These handouts, the syllabus, and other course materials are available upon request (please contact the Access to Justice Coordinator, online:

$<$ http://law.usask.ca/research/deans-forum/connect.php $>$ ).

40 Refer to Progress Report II, supra note 36 at 3-8, for a record of the developments during the summer and fall of 2015.

41 The creation of an access to justice coordinator position and the Saskatchewan Access to Justice Working Group were recommendations from the 2015 meeting of the Dean's Forum. For more information, see the Progress Report II, supra note 36 at 3-4. We acknowledge the support of the Law Foundation of Saskatchewan in the creation of the position. The problem of resources has been noted as an early and continuing problem in clinical legal education generally. Smyth, supra note 9 at 18.

42 Progress Report II, supra note 36 at 3-9, provides a general overview of the access to justice coordinator's work from 1 October 2015 to 29 February 2016 to implement access-to-justice initiatives and to prepare for the 2016 course offering of the Dean's Forum. 
for dialogue, exploration, and action on innovation, the stage was set for a third offering of the Dean's Forum and a second offering of the course.

Several changes were made to the structure of the third offering of the course in 2016 in response to both instructor and student reflections. First, this offering took a new shape as an "intensive" course, which required more serious hours of work from the students in January and February. The intensive model proved effective - it kept students engaged both in and out of the classroom, as each week there was some aspect of the project to be completed. Second, the course was re-envisioned as a capstone course, with limited enrolment of six students on an application basis, ${ }^{43}$ to better align with its objectives for collaborative action. Ongoing connections with Dean's Forum student alumni were enhanced, with invitations for them to join as collaborators during the project work or as participants in the Working Group. In this way, the course continued to deviate from the traditional template of a law course; rather than treating the course as a self-contained vessel for the consumption of knowledge, past students remained - and wanted to remain - engaged.

\section{Impact and Outcomes of the Project}

The students' work from each of the Dean's Forum meetings has begun to move into implementation and action. For example, from 2014, the topic of improving early integrated service delivery has been reported by the Ministry of Justice to have helped advance steps being taken to pilot a Justice Access Centre. The creation of the access to justice coordinator position and the Working Group were described as exciting spinoffs from the 2015 meeting. Another student project from 2015 related to the legal education topic that was aimed at creating a "Centre of Excellence for Access to Justice" was taken up by the College of Law at the University of Saskatchewan. ${ }^{44}$ In October 2016, CREATE Justice was established, a centre for research, evaluation, and action in the areas of access to legal services, dispute resolution, and systemic justice. ${ }^{45}$ A number of outcomes unfolded as a result of the 2016 discussion of "putting the public first." One such initiative was the creation of the inaugural Saskatchewan Access to Justice Week. ${ }^{46}$ Participants at the 2016 Dean's Forum identified that "a provincial strategy must embrace multiple vehicles and approaches to engagement to ensure that different communities within the public,

43 In 2016, students were selected based on their academic achievement and a written expression of interest that outlined why the student wanted to be part of the Dean's Forum, including identifying evidence of any previous access-to-justice and dispute resolution-related academic, volunteer, and employment experience or involvement in collaborative community leadership or innovative initiatives.

44 The Reaching Equal Justice, supra note 5 at 122-123, called on three Canadian law schools to establish a centre of excellence for access-to-justice research. The development of research metrics, benchmarks, and systems of evaluation was encouraged in Roadmap for Change, supra note 5 at 23.

45 To learn more about CREATE Justice, see University of Saskatchewan College of Law, "CREATE Justice: Centre for Research, Evaluation, and Action towards Equal Justice," online: $<$ http://law.usask.ca/createjustice/>. For a summary of the establishment of CREATE Justice, see "Justice Research Centre Established at the U of S," of Note College of Law Magazine (Winter 2017) at 7, online: <http://law.usask.ca/documents/alumni/ofNote_Winter2017_WEB.pdf>. The Honorary Thomas Cromwell, retired Supreme Court of Canada justice, was named an honourary fellow of CREATE Justice at the announcement of the centre, which occurred during the inaugural Saskatchewan Access to Justice Week. See "Cromwell Named Honourary Fellow of CREATE Justice," of Note College of Law Magazine (Winter 2017) at 8-9, online: <http://law.usask.ca/documents/alumni/ofNote_Winter2017_WEB.pdf>.

46 To learn more about the inaugural Saskatchewan Access to Justice Week, see the University of Saskatchewan College of Law, "Saskatchewan Access to Justice Week: October 18-25, 2016," online: <http://law.usask.ca/research/deansforum/access-to-justice-week.php $>$ ["Saskatchewan Access to Justice Week"]. For a summary of the Access to Justice Week's events, see "Inaugural Saskatchewan Access to Justice Week a Success," of Note College of Law Magazine (Winter 2017) at 6-7, online: <http://law.usask.ca/documents/alumni/ofNote_Winter2017_WEB.pdf>. 
each who face diverse access to justice barriers are both engaged and meaningfully heard." ${ }^{\text {47 }}$ The access to justice coordinator, in collaboration with Working Group members, created the Access to Justice Week as "one vehicle and approach to engage different communities in the access to justice conversation." example of an initiative that was launched during the Access to Justice Week was the "Architects of Justice Project," which increases public participation in the development of access-to-justice solutions. ${ }^{49}$

Finally, a third outcome from the 2016 topic on "putting the public first" has been the creation of the Saskatchewan Access to Legal Information Project [SALI Project], a partnership between the Public Legal Education Association of Saskatchewan, the Saskatoon Public Library, the Law Society Libraries, the University Library, and the College of Law. The goal of the SALI Project is to increase access to legal information for Saskatchewan residents. ${ }^{50}$ At this stage, the project partners are focusing on "how library representatives, as intermediaries and credible information providers, could help improve access to justice in Saskatchewan." ${ }^{51}$ The SALI Project epitomizes the impact and energy that the Dean's Forum can have on participants and advancing initiatives - that is, within only six months of the Dean's Forum meeting, the new project partners applied and were successful in obtaining an academic research grant to host an intersectoral meeting, ${ }^{52}$ the meeting was coordinated and held to identify next steps in improving access to legal information for Saskatchewan residents, ${ }^{53}$ and the implementation of those next steps is already underway.

Given the substantive aims of this initiative - to engage students in meaningful policy change - critical questions will and must arise about outcomes. An action-oriented approach is indeed central to the students' activities in the course. On reflection, it is also central to our approach as instructors and a key ingredient, we suggest, in pedagogy designed to support social change. In the remainder of this discussion, we retrospectively build a framework that connects the pedagogy of this project to its substantive aims.

47 Progress Report III, supra note 36 at 5.

48 "Saskatchewan Access to Justice Week," supra note 46.

49 For more information on the Architects of Justice Project, see the University of Saskatchewan College of Law CREATE Justice, "Architects of Justice Project," online: <http://law.usask.ca/createjustice/projects/architects-of-justiceproject.php $>$. As identified at the website, "Architects of Justice is an initiative that, through an exploratory survey, increases public participation in developing access to justice solutions. The survey, launched during the First Annual Access to Justice Week (October 2016), was designed to help us understand law in the public's life and how the justice system can be improved. This information will help to identify (i) where the public may choose to go for help when facing a legal issue; (ii) reasons people might not take action through the legal system; and (iii) how we can make it easier for people to deal with their legal problems. Survey responses will provide meaningful input to help justice stakeholders improve the justice system. Architects of Justice was created in Ontario by The Action Group on Access to Justice. The survey conducted in Saskatchewan replicates the Ontario initiative to invite Saskatchewan residents to imagine the justice system of the future."

50 To learn more about the Saskatchewan Access to Legal Information Project, visit University of Saskatchewan College of Law, "Saskatchewan Access to Legal Information Project," online:

$<$ http://law.usask.ca/createjustice/projects/Saskatchewan-Access-to\%20Legal-Information.php>.

51 Ibid.

52 Ibid. The meeting was "generously supported by a University of Saskatchewan President's Social Sciences and Humanities Research Council (SSHRC) grant."

53 University of Saskatchewan, College of Law, "PLEA, Libraries, and Access to Legal Information Project: Meeting Day Summary and Minutes from September 12, 2016" [on file with the access to justice coordinator]. The meeting was held on 12 September 2016 with justice stakeholders and library representatives from urban, rural, and remote areas of Saskatchewan in order to "start identifying their and their patrons' legal information needs and discussing what roles libraries, with PLEA's support, might play in improving access to legal information.” Particularly meaningful was that several Dean's Forum student alumni had the opportunity to participate in this spin-off project, which was related to their original Dean's Forum project of "putting the public first." For a student to see their project through, then become part of the implementation phase is unique. 


\section{REFLECTING ON THE DEAN'S FORUM AS AN EDUCATIVE ENVIRONMENT FOR SOCIAL CHANGE}

\section{A. An Action Research Orientation for Our Reflection on Course Design}

We attribute the momentum of the Dean's Forum to the way it has destabilized old routines by bringing a new approach and fresh voices into the dialogue. With each offering, it is unavoidable that patterns begin to develop that have potential to themselves become "institutional' and, in time, counterproductive. Internal and external frictions can be viewed as energizing and part of the creative process, but still deserve reflection, to support principled decisions about how to guide the project's momentum and effectively deliver future iterations of the course and the forum. We employed an action research approach to engage in such reflective evaluation. Action research is "a form of enquiry that enables practitioners ... to investigate and evaluate their work." ${ }^{, 54}$ It is a well-developed research method and form of professional learning often employed in the field of education, ${ }^{55}$ but it is rarely used in the field of legal education. ${ }^{56}$ As Jean McNiff and Jack Whitehead indicate, "[a]ction researchers ... are insider researchers. They see themselves as part of the situation they are investigating, and ask, individually and collectively, 'Is my/our work going as we wish? How do we improve it where necessary?'",57 To engage in action research requires a self-critical approach - a willingness to try something, measure its effectiveness "in action," and then make adjustments and respond "in action." McNiff and Whitehead describe this process as an "actionreflection cycle" where one engages in the process of observing - reflecting, acting, evaluating, and modifying - and moving in new directions. ${ }^{58}$

With this orientation, we set forth to reflect individually and collectively on our experience with the course over the past three years. ${ }^{59}$ The object of our inquiry was this: how do we facilitate a learning

54 Jean McNiff \& Jack Whitehead, All You Need to Know about Action Research, 2d ed (Thousand Oaks, CA: SAGE Publications, 2011) at 7.

55 Ibid.

56 In an analysis about action research in legal education two decades ago, Paul T Wangerin states that "[u]nfortunately, most legal educators have neither the time nor the inclination to engage in ... complex empirical research" but that "educational research need not be left only to education research specialists or to those with advanced training in statistical analysis; [r]ather, almost any teacher ... can conduct simple educational research." Paul T Wangerin, "Action Research in Legal Education" (1997) 33 Willamette L Rev 383 at 385-386. Over fifteen years later, Michelle Leering states: "Action research is not a term that is much used or understood in legal education." Leering, "Conceptualizing Reflective Practice," supra note 38 at 90. Parallels can be drawn with the Adaptive model of teaching. See Colleen F Shanahan \& Emily A Benfer, "Adaptive Clinical Teaching” (2013) 19(2) Clinical L Rev 29.

57 McNiff \& Whitehead, supra note 54 at 8.

58 Ibid at 9.

59 Through her own action research project aimed at encouraging reflective practice in the law school context and supporting law school curriculum reform, Michelle Leering examines the meaning and purpose of reflective practice and emphasizes the "promise of reflective practice in the context of the legal profession and at this critical juncture in the profession's history." Leering, "Conceptualizing Reflective Practice," supra note 38 at 83, 90-93. Leering provides further insight about how reflective practice and action research can help to support a culture of innovation among justice stakeholders - including legal educators - in order to help improve access to justice. Michele Leering, "Creating a Capacity for Innovation in Legal Professionals: The Gift and Promise of Reflective Practice and Action Research for Fostering Access to Justice" (2017) Windsor YB Access Just [forthcoming]. The power of action research and critical reflection has been emphasized previously, e.g., in Stephen Kemmis, "Action Research and the Politics of Reflection" in David Boud, Rosemary Keough \& David Walker, eds, Reflection: Turning Experience into Learning (New York: Kogan Page, 1985) 139 at 141, in which Kemmis states: "We are inclined to think of reflection as something quiet and personal. My argument here is that reflection is action-oriented, social and political. Its "product' is praxis (informed, committed action), the most eloquent and socially significant form of human action." 
environment that is most conducive to supporting social change, through the operational lens of public policy? Have our pedagogical choices been effective towards this goal? How can we improve our practice? Our reflective enquiry is enhanced by the multiple voices and perspectives our individual reflections embody. We have each engaged with the project in two of the following roles: student, course instructor, and faculty member. To facilitate our inquiry, we undertook to record our individual reflections from the perspective of each of our embodied roles; then, collectively, we identified common themes and observations. From here, we drew from the literature in clinical legal education to provide a theoretical framework for our experiences. The following section is a presentation of what we discovered through our reflective inquiry, presented as a dialogue between the theory and our collective and individual voices. B. Building Our Pedagogical Toolkit for Social Change

Because the pedagogical structure of the Dean's Forum was developed "in action," we were able to align it with the evolving character and orientation of the Dean's Forum project itself. We employed a reflective practice from the onset of the project and made continual adjustments to achieve our goals. In the process, we uncovered several features that have turned out to be essential to the initiative. At its core, the Dean's Forum was rooted in a quest for social, institutional, and cultural change, and this goal has been transparent in its structure, approach, and delivery throughout.

The traditional learning environment and its pedagogical tools are primarily focused on the transference of knowledge to students. However, Robert VanWynsberghe and Andrew Herman posit that knowledge alone cannot produce social change without corresponding action and, further, that action is reflective of normative habits and routines (institutional, systemic, and individual): "[T] he more imposing forms of social structure exist only because of the routines we carry around with us." ${ }^{\circ 0}$ Thus, VanWynsberghe and Herman suggest that "to design educative environments to affect action, we might have to work to change contexts, frustrate habits and spur creative problem solving." ${ }^{.61}$ In this way, "[i]f knowledge is not the only

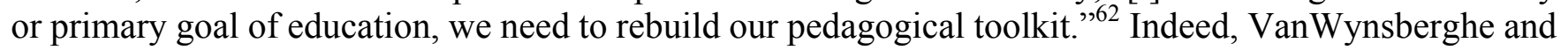
Herman identify five features essential to designing educative environments that facilitate social change: engaging with stakeholders, real world learning, off campus learning, transdisciplinarity, and nontraditional rewards. The Dean's Forum course contains to varying degrees each of these essential features, and each has presented its challenges.

\section{Engaging with Stakeholders and Frustrating Higher Order Routines}

VanWynsberghe and Herman suggest that students engaging with stakeholders can produce powerful learning and social change outcomes:

To more effectively bring about system-wide change, it is important to engage institutional actors in the educative environment. Stakeholders, governments, business leaders and

60 Robert VanWynsberghe \& Andrew C Herman, "Education for Social Change and Pragmatist Theory: Five Features of Educative Environments Designed for Social Change" (2015) 34:3 International Journal of Lifelong Education 268 at 277, online: $<$ http://dx.doi.org/10.1080/02601370.2014.988189>.

61 Ibid at 274. For examples of educative environments that are aimed at affecting action, see Rob VanWynsberghe \& Janet Moore, "Classroom as a Social Movement Organization" (2008) 6:3 Policy Futures in Education 298, online:

$<$ http://pfe.sagepub.com/content/6/3/298.short>; Suzanne Dudziak \& Norma Jean Profitt, "Group Work and Social Justice: Designing Pedagogy for Social Change" (2012) 35:3 Social Work with Groups 235, online:

$<$ http://www.tandfonline.com/doi/pdf/10.1080/01609513.2011.624370?needAccess=true $>$.

62 VanWynsberghe \& Herman, supra note 60 at 278. 
activists should be engaged in the learning process with students in order to frustrate not only the routines of individuals, but also higher order routines as well. ${ }^{63}$

Indeed, the leadership role given to students through the course required that normal policy-making power structures - higher order routines - be loosened. It invited the students' hopeful perspectives into difficult conversations and allowed us to explore tricky issues without the normal positioning around that dialogue. No single organization or stakeholder group was expected to take the lead or to position itself in conventional ways. Exploratory conversations could make more rapid progress, feeling out areas of consensus and possibility, in a neutral space with fresh, informed, and unencumbered facilitators.

For students engaged in social justice-oriented clinical placements, the concept of sharing power is not new. Clinical students are encouraged to be patient with the process of internal disruption, encouraged to identify and consider sharing their own sources of power. A "(c)ommitment to working alongside communities requires constant reflection on power dynamics, and the willingness to surrender the comfort that the acquisition of professional knowledge can bring., ${ }^{, 64}$ What is fascinating and perhaps unexpected about our project is that we were able to tap into a different kind of transference of power as institutional players demonstrated a willingness to let go of the reins:

Traditionally, one must bide their time and pay their dues before they are seen to have earned the privilege of having standing in such high level debates - possessing sufficient social capital to offer something constructive to the dialogue. Inviting me into the dialogue - and not only permitting me into the room but giving me the floor - this was powerful. It was an "ah-ha" moment that transformed me from passive receiver of information (student identity) to active participant (professional identity). It signalled that my power to contribute is not dictated by external factors, but that I possessed within me already the necessary skills and capacity to think creatively about complex social issues and to offer my perspective and energy to help craft solutions.

- Student reflection

The idea of exploratory and self-determined learning, through the transfer of power to a student, is familiar in the context of experiential learning initiatives. One might see this idea as central to adult education and clinical legal education in particular. Adult learners are known to learn best in an environment of "mutuality of control and respect," which at least partially levels the relationship between teacher and student. ${ }^{65}$ Most clinical teaching is therefore modeled on a "mutually inquisitive and non-directive supervisory relationship between teacher and student." levelled relationships all around the student:

The Dean's Forum provided the very creative, collaborative, change-inducing outlet that we sought. As students, we were struck by the unheard of opportunity, and intrigued by how the course disrupted the hierarchical norms we had become used to after two years of law school - and by how many participants embraced this disruption.

- Student reflection

63 Ibid at 278.

64 Vasey, supra note 6.

65 Ford, supra note 21 at 118.

66 Ibid at 119. 


\section{Non-Traditional Rewards: Engagement, Connection, and Contribution}

The policy-making exercise re-engaged the student imagination and reconnected the personal and the professional in a way that clinical placements are designed to do. Becky Jacobs suggests that clinical placements reach their potential when focused on the "purposeful cultivation of curiosity." ${ }^{67}$ Intellectual curiosity has been described as one of the most important determinants of academic success and also as a potential resource. ${ }^{68}$ If a professor can tap into a student's curiosity, the students' natural commitment to the pursuit of real world experience can be used to explore the contours of social change. ${ }^{69}$ Curiosity can be dispositional - what the student already brings to the table:

\section{Prior to and during law school, we passionately sought out opportunities that could help advance social change and the public interest in the justice system.}

- Student reflection

Or, curiosity can also be situational - viewed as a "learnable skill" 70 - coached out of the student, inviting them to think of these broader questions while engaging in the task at hand:

Some students reported having come to the class with minimal appreciation for the accessto-justice crisis, but leaving the course with an acute understanding of it as one of the most pressing challenges facing the justice system.

- Instructor reflection

Either way, the invitation to students to consider themselves agents in the creation of justice policy clearly cultivated curiosity - purposely - and at a wholly different level.

It has been said that the traditional law school curriculum and environment that tends to lead students who come to law school with social justice motivations to abandon or retreat from such motivations (or to relegate such motivations to the private realm) and to instead adopt a dispassionate relationship with the law as a neutral arbiter of legal problems. ${ }^{71}$ While clinical programs have explicitly offered a critical counter-narrative and provided space for such motivations to be reflected in the learning environment, ${ }^{72}$ the traditional clinical model of individual client advocacy can lead some students to adopt a narrow view of the ability of independent legal solutions to impact broad systemic issues or can reinforce a limited role

67 Becky Jacobs, "Cultivating Purposeful Curiosity in a Clinical Setting: Extrapolating from Case to Social Justice” (2015) 21 Clinical L Rev 371, online: <http://papers.ssrn.com/sol3/papers.cfm?abstract_id=2628745>.

68 Ibid at 373.

69 Ibid. In a recent article, Kim Brooks sets out curiosity combined with creativity, innovation, and collaboration as one of nine fundamental guidelines for legal education curriculum reform. To this end, she argues that "[p]erhaps one of the reasons why law and legal practice have been so slow to adapt to the challenges of access to justice and the antiquated business model of many law firms is that law schools failed to provide students with enough creative spark to do anything different." Kim Brooks, “The World Needs More Rod Macdonald: The Potential of Big Ideas" (2014) 51:4 Alta L Rev 871 at 883.

70 Jacobs, supra note 67 at 381.

71 Robert Granfield, Making Elite Lawyers: Visions of Law at Harvard and Beyond (New York: Routledge, 1992) at 90; Stuart Scheingold \& Austin Sarat, Something to Believe In: Politics, Professionalism, and Cause Lawyering (Stanford: Stanford Law and Politics, 2004) at 54-58.

72 Shelley AM Gavigan, "Twenty-Five Years of Dynamic Tension: The Parkdale Community Legal Services Experience" (1997) 35:3 Osgoode Hall LJ 443 at 468; Jane Aiken, "The Clinical Mission of Justice Readiness” (2012) 32 BCJL \& Soc Just 231 at 236; Janelle Anderson, "Clinical Legal Education: Perspectives from Former Clinical Law Students" (2013) 37:1 Manitoba LJ 427 at 433. 
of lawyers within such existing institutions. ${ }^{73}$ The Dean's Forum, with its explicit focus on critical systemic reflection and an action-oriented approach towards forms of systemic change, provides an outlet for such social justice motivations and gives students the opportunity to align their efforts with their desire for contributing to systemic change: ${ }^{74}$

We knew we were part of something different and revolutionary even as it was unfolding. The energy this created made engaging with the work not feel like "work" - it was inspiring, interesting, and thought provoking. I became motivated not by the prospect of a good grade but by something bigger than self-interest - by feeling part of something important. We knew it was a privilege to participate in the course and be on the cusp of innovation in Saskatchewan.

- Student reflection

The opportunity to engage in this way produced immediate rewards for students. The upset in normal hierarchies (for example, a student sitting at the table alongside the province's chief justice; each viewed as equally influential in setting the direction of the event) was obvious to the students. ${ }^{75}$ We believe this compensated for the absence of the traditional course structure and accompanying system of clear instructor-generated expectations, reference materials, and doled-out rewards. The rewards had to be found, instead, in the momentum and meaning of the activity itself.

Rewards were also found in the purposeful and instrumental nature of the students' work, which proved a marked contrast to the traditional objectives of their usual academic routines:

In contrast to the dissatisfying nature of typical course work (where the end result of a carefully constructed academic paper is to get the mark and file the paper away), the prospect of engaging with real people and real problems was so rewarding. It was truly satisfying to have purpose and a practical application for the skills I had developed throughout school, knowing that I was grappling with current issues, and crafting a report for an audience that was going to do something with the work I produced. My work would make a contribution.

- Student reflection

It is worth noting that the reward system that grew from the disruption of higher order routines extended beyond the students to instructors, other faculty, and outside participants:

It is not a surprise that the reflections we have heard from some participants include it having been a "transformative experience." In pairing diverse stakeholders' learning with

73 Buhler, supra note 3 at 127; Mosher, supra note 1 at 634.

74 The benefits that reflective practice, a core competency in other professions, offers for enhancing the education of legal professionals, starting in law school is explored in Michelle Leering, "Reflective Practice \& Reflective Inquiry: A Critical Imperative for Enhancing Law Student Learning and Legal Professionalism" (2016) Can Bar Rev [forthcoming].

75 Interestingly, the idea of destabilizing traditional professional relationships - beginning with that between the professional (lawyer, for example) and the client - is commonly a part of educational initiatives in the social justice area. Vasey, supra note 6 at 13: "Social justice, then, requires destabilizing traditional lawyer-client and social worker-client relationships, in which the client is always subordinate to the professional, the expert knower." 
students', the process seems to create a healthy mix of vulnerability, optimism, and creativity among participants.

Benefits transferred to the College of Law as well. In the social justice arena, burnout is common - with progress advancing incrementally, sometimes slowly, leading to individual and organizational fatigue:

We experience that as instructors, too. Where our instruction is attached to hopes for transformative impact and social change - not just in our students but in the system that surrounds us - this can be tiring. Alongside those delivering services at the community level, we can become discouraged by the "fits and starts." The involvement of students with their creative energy and unfettered vision to move forward on projects that reached beyond the academic realm - was inspiring. It has carried us along with it.

- Instructor reflection

Renewed energy spilled over into our faculty's research agenda as well. Since student projects and the Dean's Forum itself were relatively open and visible, they inspired conversations among individual faculty about common research and teaching interests in the area of access to justice. In a way that is hoped for, but usually hard to achieve, we became conscious about the points of connection in our work, even across substantive disciplines. The forum's continuation (and its spreading network across the curriculum ${ }^{76}$ ) are support for the idea of meaningful engagement as its own reward system - for students, faculty, and other participants.

\section{Real World and Off-Campus Learning and Trans-Disciplinarity: Balancing Creativity and Structure in Course Design}

The student experience has extended beyond the four walls of the classroom and into the real world at various stages of the course. The process of the Dean's Forum connected students with stakeholders within the profession during the course of the information-gathering phases and the forum meetings themselves. On a level designed for the exploration of policy, students have ventured "out," and we have invited the real world "in":

This type of encounter with the real world of the legal system was eye opening. I was diligently studying in law school in order to gain access into a system I really knew very little about. As I encountered different opinions and insider knowledge about the legal system, I gained valuable perspective. This was a form of practical and relational learning I could not have obtained from a textbook. It is the kind of learning that can only be obtained through direct engagement outside of the classroom setting.

76 See Progress Report I, supra note 36 at 2-3; Progress Report II, supra note 36 at 4-6, for student contributions undertaken through Sarah Buhler's access-to-justice course. Student "individual directed research projects" (IDRs) have also been undertaken since 2015 to advance the implementation of Dean's Forum recommendations. E.g., IDR work was undertaken by students in both winter 2014 and winter 2015 to advance the potential of creating an Access to Justice Centre of Excellence at the University of Saskatchewan. Since the access-to-justice position was created in fall 2015, increased coordination of student research and project work was possible during fall 2016 - four IDR projects cocoordinated by the access-to-justice coordinator and supervised by various faculty were undertaken, addressing the topics of restorative justice, unbundling and legal coaching, access-to-justice syllabi in legal education, and mandatory "appropriate" dispute resolution pre-petition in Saskatchewan family matters. 
- Student reflection

Consistent with the project's orientation, we have seen the students frustrating "habits of the real world" as soon as they started the consultation phase of their projects with justice and community members off campus as well as their own. From the beginning, the students had to find a different model for their work, a model that fell completely outside law school's standard methodology. The typical substantive law class model involves primarily independent work, immersed in case law, lectures, papers, and/or exams. The whole enterprise is bound by the infrastructure of the academy - textbooks, case books, libraries, independent (and often competitive) learning, and didactic lectures:

I felt I had become quite adept at being a student and succeeding within this model. But this model had none of the features of the real world. The real world and real legal issues bear no resemblance to the curated scenarios of the classroom - the real world is messy, complex, and often contradictory.

- Student reflection

The Dean's Forum had none of the elements of the typical law course. The whole project was collaborative, from the design of the projects, the group work, and the dialogue with stakeholders at the forum itself. There was no topical case list, no identification of learning objectives that would be distilled from diligent and engaged reading, no final exam or hypothetical scenarios, and no clear boundaries on what would or would not be covered during the term. In this way, engaging in such a course was unsettling - certainly uncharted territory:

I remember feeling uncertain about how to proceed or whether I was performing my role correctly as we went along. I had become accustomed to the safety and predictability of the traditional model. But this new approach was also exciting.

- Student reflection

According to Supreme Court of Canada's Chief Justice Beverley McLachlin, four of the top qualities essential in today's lawyer are "creativity," "empathy," "adaptability," and "breadth of perspective" each of which, we think, are consistent with social justice aims. ${ }^{77}$ They invite interdisciplinarity. ${ }^{78}$ In the context of social justice lawyering, these qualities move the law student beyond traditional advocacy into other roles, including the "collaborative" and "democratic" lawyer. ${ }^{79}$ Adam Vasey envisions the lawyer as responsive, empathetic, consultative and problem solving with the people that she serves. In retrospect, we developed a course structure around those objectives. We invited students to consider at every stage "how might I approach this particular problem?" if those were their aims (to be responsive, empathetic, consultative, and problem solving). We were driven by the ideal - a value-driven (interest-based) set of goals - as the frame for the whole course, creating a congruence between the democratic and collaborative nature of both our methods and our substantive aims.

77 Beverly McLachlin, "The Legal Profession in the $21^{\text {st }}$ Century” (Lecture delivered at the 2015 Canadian Bar Association Plenary, Calgary, Alberta, 14 August 2015) at 18, online: <https://malcolmmercer.files.wordpress.com/ 2015/08/cj-mclachlin-remarks-august-14-2015-2015-cba-legal-conference.pdf $>$.

78 The value of interdisciplinarity in education with social justice aims is noted in Vasey, supra note 6 at 6.

79 Ibid at 43. 
Indeed, interest-driven, mediation-like principles infused both our frame for teaching and structuring the course. "Teacher" was envisioned as "facilitator," adapting from class to class and from year to year in order to support the needs of the students in advancing their projects. We were, as David Straus describes, "process guides," and, at times, we "stepp[ed] out of role to offer expertise or an idea from past experience in dealing with a specific substantive issue." ${ }^{\circ 0}$ With respect to the interest-driven structure of the course, students were referred to mediation principles and collaborative policy-making materials such as Straus' article to consider their role in the initiative as facilitators and to reflect on how those principles could infuse the way they approached their consultations, written work, and presentations. ${ }^{81}$ Students were pressed continually to "step into the shoes of others" (a conceptual tool that enhances mediation) in identifying the issue to be solved, whom to consult, and how to present results. Along with considering justice and community stakeholders' interests and needs, students were challenged in new ways to look at the legal system from the public's perspective.

This idea of adopting an outward-looking focus to prioritize and seek to understand the diversity inherent in the users of the justice system has been identified as a guiding principle for justice reform. ${ }^{82}$ Some argue that law students should be exposed to diverse perspectives to prepare them for a "publiccentred" justice system: "Additionally, skills learned in law school should include an appreciation of the importance of 'putting the public first.' This means becoming attuned to legal needs as defined by the user, and recognizing the implementation gap between the everyday legal problems that are pervasive in the lives of Canadians and the ability of legal services to address these problems." 83 The Dean's Forum initiative has encouraged students to look outward - to identify diverse public needs and gaps in order to then address those needs in a way that is consistent with conventional thinking around consensus-building processes (that they be "inclusive, not exclusive" and have "respect for diverse interests"

As a facilitator, more than "conveyer of knowledge," the instructor is called to step back - to invest trust in the process and embrace a co-creative role. After the first iteration of the course, when momentum dictated a looser approach, we found ourselves reaching for the comfort of traditional teaching models a natural place to go as the teaching role in the project was taken over by the two of us who had just graduated from law school. Deep entrenchment in the Dean's Forum project did not necessarily mean it was easy to move into the instructor role:

To be a good instructor, I wanted to be what I valued in other instructors - provide clearly articulated learning objectives, set out a clear timeline for the course, identify topical classroom sessions, facilitate engaged and informed discussion, provide all the resources that students would need to succeed, be available and flexible to student needs. Above all, looking back, I wanted to be in control of the process - have a high level view and know as things unfolded exactly how they fit into the overall design ... [W] compensated for our lack of experience with additional course infrastructure in order to add credibility to the process.

- Instructor reflection

80 David Straus, "Managing Meetings to Build Consensus" in Lawrence Susskind et al, eds, The Consensus Buildling Handbook: A Comprehensive Guide to Reaching Agreement (Thousand Oaks, CA: SAGE Publications, 1999) 287 at 298-299.

81 Ibid at 298-299. See also Trevor CW Farrow, "What Is Access to Justice?” (2014) 51 Osgoode Hall LJ 957.

82 Roadmap for Change, supra note 5 at iii, 7. See also Farrow, supra note 81.

83 Aylwin, supra note 9 at 55.

84 Part of Cormick et al, supra note 17 at 7. 
"Content" was added to the course - materials on collaborative policy-making, group decision making, process principles - resources that supported the real-world, community-based, interdisciplinary setting into which students were reaching. These filled in areas of much needed guidance, but along with structure for the course came some erosion of the collaborative, agile, co-creative classroom environment that was so productive the first time around. Noticing the shift, we invited students into a leadership role within the course structure. We reflected and adapted, acting on our authentic desire for them to take ownership of the project; we have continually eased back from positions of control or authority.

As we wrestled with the balance, we have learned that this works best when students bring some maturity (or, at least, "educational" maturity) to the exercise and a readiness to step outside traditional course structure and into dynamic roles. The changes adopted in our third iteration of the course - making it a capstone course by invitation or acceptance only, reducing the class size, and employing an intensive model - helped create the right foundation for the kind of work the course required. Now that we are moving into the course's fifth generation, we continue to feel the tension between innovation and structure. The risk that students will fall into conventional learning patterns and seek to simply replicate "what was done before" continues to grow. We trust the adaptive and mediative frame that has been developed for the course - its focus on process values - and view this as an essential vehicle for outreach (real world, off-campus) and interdisciplinarity in the context of our project.

\section{Engaging with Stakeholders and Inviting Students to Wrestle with Competing Goals}

This brings us to the exercise of outreach and community engagement itself, and the challenges that it presented. As noted, beneath the Dean's Forum project was the assumption that outreach and community engagement need to be central to the development of a "public-centered understanding on access to justice." 85 Decades ago, Rod MacDonald located a "public voice" at the heart of questions about law reform and access to justice, ${ }^{86}$ more recently, Trevor Farrow returns to the same point:

[T] he voices in the room have almost invariably been those of academics, lawyers, judges, government representatives, and the like. When voices of the public are heard, they are typically the voices of those who have been involved in the justice system - current litigants or those who have previously used the system in some way. All of these people and groups are clearly important and will ultimately be part of an access to justice solution. However, over that period of time, I have increasingly heard myself saying: "If we ask regular people on the street what they feel and understand about justice and access to it, we might get a very different view." 87

85 Farrow, supra note 81.

86 Rod MacDonald made the same argument as Farrow in 1990, stating: “[O]ur general knowledge about the public's perception of access to justice remains impressionistic. We know surprisingly little about the legal needs of the public, about its need for the services of lawyers and notaries, and about the correlation which members of the public make between justice and law." Roderick A MacDonald, “Access to Justice and Law Reform” (1990) 10 Windsor YB Access Just 287 at 328. MacDonald further noted that the access to justice movement of the 90s was based on an assumption that the public wanted "access to the system, however imperfect it may be," and that no related empirical research had been undertaken to inquire with the public. He argued it could be speculated that "the most important need of the public was to feel empowered - not by gaining access to formal institutions for applying the law as written, but by having access to their own institutions where more localized conceptions of justice could be developed and applied" (at 302).

87 Farrow, supra note 81 at 959. 
Farrow's view of this long-standing and now pressing challenge is simple: "[I]t is time to put the voice of the public at the centre of how we think about and address current efforts to reform access to justice." 88 Putting this into practice in the design of collaborative policy-making initiatives is not so easy, and we encountered those challenges both in the project itself and in our management of the teaching role.

In the social justice arena, one tension is how to meet the hopes and expectations of a community that may be experiencing research exhaustion:

Our students were welcomed by community groups and organizations, and enjoyed long conversations about "what could be done." Activists, social workers, lawyers, judges, community outreach workers all demonstrated their willingness to talk, with quiet and resilient energy. Our outreach could have and should have taken us deeper into the arena of those affected by "access to justice barriers." Concerns about the misappropriation of "voice" ought to have led to invitations to all those consulted, to sit at the policy-making table. And yet, pragmatic decisions had to be made and multiple objectives balanced.

\section{- Instructor reflection}

Allowing students to wrestle with some of these dilemmas (rather than dictating to them) was part of the reward system created around the course. We facilitated, offering guidance on how to deal with competing interests in engagement and outreach. We helped students reason through, for example, whether it was more important to include a large group of participants during the meeting day to canvas as many perspectives as possible or to have a smaller number of participants and create a more decisive meeting environment. Students sorted through these competing interests. Could diverse voices be brought to the table in other ways? The same mediation principles that helped us offer guidance have helped students in their decision making around engaging with stakeholders and contemplating competing goals:

\section{I had studied negotiation, mediation, and was concurrently practising and competing as part of the law school's Mediation and Mediation Advocacy Moot Team. It was meaningful to apply my knowledge in mediation principles to the consensus building, collaborative policy-making exercise. The engagement with stakeholders leading up to the meeting day was an important aspect of building consensus.}

- Student reflection

The Dean's Forum has now embraced a rolling invitation list that may vary from gathering to gathering. A core group of decision makers typically attend, and, each year, the students identify various interest groups related to the topic area and plan around an ideal group size. For example, when the legal technician/paralegal topic was discussed, a greater number of Law Society of Saskatchewan representatives were invited; when the topic of how the Court of Queen's Bench and its procedures could be more accessible was addressed, as was previously stated, more justices were invited. The students who were part of the "putting the public first" group decided that there were too many "publics" to invite to the table and so opted to only invite a select number, but they arranged a roundtable with a number of community-based organization representatives to elicit diverse perspectives during their consultation

88 Ibid at 965. Similarly, MacDonald recently argued: "Over the past four decades, there has been a vast corpus of writing about law reform, by professionals (most often law professors), aimed at other professionals, and far too little writing about law reform either by non-professionals or aimed at the general public." MacDonald, "Law Reform for Dummies," supra note 18 at 865 . 
process. How to engage the public voice with integrity is a challenge shared by all policy-makers with a concern for accessible justice, and we cannot claim to have solved that dilemma. However, inviting students to wrestle with how to accomplish such a goal fit with the student learning objectives that guided us. ${ }^{89}$

\section{CONCLUSION: A CONTINUOUS PROCESS OF REFLECTION AND EVOLUTION}

"[Hope] is not the conviction that something will turn out well, but the certainty that something makes sense, regardless of how it turns out." ${ }^{.90}$ Vaclav Havel's famous quote captures something unique about the Dean's Forum project at our College of Law, the combined forces that landed students at the centre of a policy-making exercise and the collective relinquishment of higher order routines. If we are looking to legal education to train legal professionals for the future, and we know that the legal future must look radically different from the legal present, then this model may work. It can connect curiosity with conviction, nurturing a critical perspective, an innovative spirit, and trust in one's voice and in new habits of engagement and collaboration. Indeed, VanWynsberghe and Herman argue that lessons that students learn in an educative environment designed for social change have the potential to "endure ... because creative engagement in non-traditional educational activities have the potential to form habits ... that are employed outside the classroom. ${ }^{.91}$ By creating the space for law students to engage in crafting solutions to complex social dilemmas in action, collaboratively with stakeholders who also engage in action, we have experienced a powerful force that is, in real time, reorganizing and reconstructing the social structures that we seek to evolve. ${ }^{92}$ Indeed, the Dean's Forum course meets the very calls to action and unorthodox research that, among others, the CBA's Reaching Equal Justice, ${ }^{93}$ A Roadmap for Change, ${ }^{94}$ and scholars such as MacDonald suggest. ${ }^{95}$

We have noted the risk of co-option. In time, the Dean's Forum may establish its own "habits" and "routines" that diminish the transformative power of its destabilizing potential and, by extension, inhibit its ability to affect social change. This calls for constant evolution and innovation in the structure and format and frequent reflection with assistance from the action research model. We should consider closely what students need to continue engaging as they have as well as what other agents inside and outside the Dean's Forum may need. The project's first four years have been defined by a forward-looking approach, but some degree of "looking back" will be required. On the College of Law's end, a challenge will be to keep new faculty involved and not let the project fall back to the same core group of people. New iterations of the project may need to grow, and people will continue to need to feel their impact upon it. Within the story of this Saskatchewan project are claims about the altruistic nature and power of the project. It has

89 Also, this led us to the conclusion that courses in our dispute resolution stream (negotiation, and/or mediation, for example) could be considered an asset - or a criteria - for students applying for the Dean's Forum course.

90 This is an oft-cited quote attributed to philosopher Vaclav Havel, Disturbing the Peace, quoted by Eric Young, "Foreword" in Frances Westley et al, Getting to Maybe: How the World Is Changed (Toronto: Vintage Canada, 2007) vii.

91 VanWynsberghe \& Herman, supra note 60 at 281.

92 In a series of interviews, the College of Law asked current and past Dean's Forum students: "How has the Dean's Forum course impacted you or helped prepare you as one of tomorrow's lawyers, and why are you passionate about the initiative?" See Dean's Forum - College of Law, University of Saskatchewan YouTube Video, online:

$<$ https://www.youtube.com/watch?v=sbJY9gQb6wU $>$.

93 Reaching Equal Justice, supra note 5.

94 Roadmap for Change, supra note 5.

95 MacDonald, "Law Reform for Dummies," supra note 18. 
this genuine essence in the way students and justice representatives have continued to engage. But, in the same way that clinical students are taught to think critically by constantly "checking" their interactions and sources of power, we need to continue the same kind of vigilant evaluation of the Dean's Forum project and its dynamics.

Drawing on Havel's concept of hope, the Dean's Forum project "makes sense," right here and right now. With today's understanding of the scope of the access-to-justice problem, it makes sense that we engage law students in projects that reach for systemic change in all possible ways. This may require some pedagogical openness in terms of how we construct courses and engage individually as teachers and students in the law school environment. The Dean's Forum experiment, so far, has been a living example of how moving outside our institutional comfort zones - supporting action with critical reflection - can lead to exciting results. 